\title{
Investigation of Some Preparation Procedures of Fatty Acid Methyl Esters for Capillary Gas-Liquid Chromatographic Analysis of Conjugated Linoleic Acid in Meat
}

\author{
Shin-ichi TAKENOYAMA, Satoshi KAWAHARA ${ }^{1}$, Hisashi MURATA ${ }^{1}$ \\ and Kiyoshi YAMAUCHI ${ }^{1}$ \\ The United Graduate School of Agricultural Sciences, Kagoshima University, \\ Kagoshima-shi 890-0065, Japan \\ ' Faculty of Agriculture, Miyazaki University, Miyazaki-shi 889-2192, Japan
}

(Received February 8, 1999 ; Accepted June 10, 1999)

\begin{abstract}
The five most widely accepted procedures for preparing fatty acid methyl esters in food lipids were investigated for their suitability in capillary gas-liquid chromatographic analysis of cis-9, trans-11 conjugated linoleic acid (c-9, t-11 CLA) in meat. A modified procedure of fatty acid methyl esterification was developed and the method was applied to determine c-9, $t-11$ CLA content in some meats. This method involved hydrolysis of lipids with $0.5 \mathrm{M} \mathrm{KOH}$ in methanol at $100^{\circ} \mathrm{C}$ for $5 \mathrm{~min}$, followed by esterification with aqueous $\mathrm{HCl}(35 \%) /$ methanol $(1: 1 \mathrm{v} / \mathrm{v})$ at $100^{\circ} \mathrm{C}$ for $5 \mathrm{~min}$. The resulting c-9, t-11 CLA methyl ester was separated by gas-liquid chromatograph equipped with a capillary column and determined using tricosanoic acid as an internal standard. Meat from ruminant animals considerably contained more $\mathrm{c}-9, \mathrm{t}-11 \mathrm{CLA}$ than those from non-ruminant animals in the following order : goat meat, beef, mutton, pork, and chicken. The amount in goat meat $(6.35 \mathrm{mg} / \mathrm{g}$ lipid) was 10-fold greater than those in pork and chicken.
\end{abstract}

Animal Science Journal 70 (5) : 336-342, 1999

Key words : Conjugated linoleic acid, Meat, Determination, Lipids

Conjugated linoleic acids (CLAs) have recently been studied by a number of researchers as one of the bioactive substances in food. CLAs are positional and geometrical isomers of linoleic acid, and they have conjugated double bonds at positions 9 and 11 or 10 and 12. In these isomers, cis-9, trans-11 CLA (c-9, t11 CLA) which is found in beef ${ }^{137}$ has beneficial effects such as antimutagenic activity and serum cholesterollowering activity $4,5,8,10,12)$. Hughes et al. ${ }^{7)}$ suggested that $\mathrm{c}-9, \mathrm{t}-11 \mathrm{CLA}$ is produced by linoleate $\Delta^{12}$-cis, $\Delta^{11}$-trans isomerase, which is an enzyme synthesized in a rumen bacteria. Chin et al. ${ }^{27}$ and $\mathrm{Ha}$ et al. ${ }^{6)}$ has found that meat, milk, and related processed food from ruminant animals contain a larger amount of c9, t-11 CLA as compared with other types of food from non-ruminant animals.
On the other hand, CLAs are easily isomerized and oxidized during the preparation of their methyl esters $^{2,14)}$. According to the literatures of Chin et al. 2) and Shantha et al. ${ }^{14)}$, decomposition of $\mathrm{c}-9, \mathrm{t}-11$ CLA isomer during methylatiom was in the range of $3 \%$ to $57 \%$ for the AOCS official method which involves methanolic sodium/potassium hydroxide followed by boron trifluoride in methanol, $5 \%$ for methanolic hydrochloride and $28 \%$ for methanolic sulfuric acid. Because CLAs are minor ingredients in food, it is important to develop a highly reliable method for determining them, especially $c-9, t-11$ CLA. Thus, the authors attemped to investigate whether the most widely accepted methods for preparing fatty acid methyl esters from food lipids could be applicable to determine the c-9, $\mathrm{t}-11$ CLA in foods.

Corresponding : Kiyoshi YAMAUCHI (fax : +81 (0) 985-58-7204, e-mail : a0b301u@cc.miyazaki-u.ac.jp)

Anim. Sci. J. $70(5): 336-342,1999$ 
A precise and reproducible method for determining the CLA in foods was proposed and used to determine the $\mathrm{c}-9, \mathrm{t}-11 \mathrm{CLA}$ content in various meats.

\section{Materials and Methods}

\section{Materials}

Conjugated octadecadienoic acid (a mixture of cisand trans-9,11- and -10,12-octadecadienoic acids, described as free CLAs standard in this paper), conjugated octadecadienoic acid methyl ester (a mixture of cis- and trans-9,11- and -10,12-octadecadienoic acid methyl esters, described as CLA methyl esters standard in this paper), and tricosanoic acid were purchased from Sigma Chemical Company (St. Louis, $\mathrm{MO}$ ). A four percent $\mathrm{HCl} /$ methanol was obtained from Tokyo Chemical Industry Co., Ltd. (Tokyo), and $14 \% \mathrm{BF}_{3} /$ methanol, 1,1,3,3,- tetramethylguanidine, aqueous hydrochloric acid (35\%, super special grade) and other chemical materials were from Wako Pure Chemicals Industries Ltd. (Osaka).

Commercial domestic and imported beef (round), pork (ham), and chicken meat (thigh) were used as samples for the determination of $\mathrm{c}-9, \mathrm{t}-11$ CLA. Round meat from carcasses of goats and sheep raised with roughage on Sumiyoshi Ranch, Miyazaki University, were also used. All samples were stored at $-80^{\circ} \mathrm{C}$ until use.

\section{Lipid extraction}

Total lipids were extracted from meat following the method of Folch et al. ${ }^{3)}$, and their lipid content was determined by the gravimetric technique.

\section{Preparation of fatty acid methyl esters (FAMEs)}

The following five methods were used for the preparation of FAMEs of beef lipid and free CLAs standard : Method $\mathrm{I}^{1}$, lipids $(30 \mathrm{mg}$ ) were saponified with $5 \mathrm{ml} 0.5 \mathrm{M} \mathrm{KOH} /$ methanol at $100^{\circ} \mathrm{C}$ for $5 \mathrm{~min}$, then esterified with $5 \mathrm{ml}$ of $14 \% \mathrm{BF}_{3} /$ methanol at $100^{\circ} \mathrm{C}$ for $5 \mathrm{~min}$ in a boiling water; Method $\Pi^{11}$, lipids $(30 \mathrm{mg}$ ) were directly esterified with $1.5 \mathrm{ml}$ of $8 \% \mathrm{BF}_{3} /$ methanol in the presence of $1 \mathrm{~m} l$ benzene at $100^{\circ} \mathrm{C}$ on a heat block for $10,15,20,25,30$ or $60 \mathrm{~min}$, respectively ; Method $\mathrm{II}^{5}$ ), lipids (30 $\mathrm{mg}$ ) were directly esterified with $6 \mathrm{ml}$ of $4 \% \mathrm{HCl} /$ methanol at $100^{\circ} \mathrm{C}$ on a heat block for $10,15,20,30$ or $60 \mathrm{~min}$, respectively ; Method $\mathrm{I}^{14,15)}$, lipids $(30 \mathrm{mg}$ ) were directly es- terified with $2 \mathrm{ml} \quad 1,1,3,3$, -tetramethylguanidine/ Methanol $(1: 4, \mathrm{v} / \mathrm{v})$ at $100^{\circ} \mathrm{C}$ in a boiling water for $10 \mathrm{~min}$; Method $\mathrm{V}^{9}$, lipids (30 mg) were saponified with $1.0 \mathrm{ml} 0.5 \mathrm{M} \mathrm{KOH} / \mathrm{methanol}$ at $100^{\circ} \mathrm{C}$, then esterified with $0.4 \mathrm{ml}$ aqueous $\mathrm{HCl} /$ methanol at $100^{\circ} \mathrm{C}$ on a heat block. In Method $\mathrm{V}$, saponification of lipids was preliminarily examined for 5 and $10 \mathrm{~min}$, both the 5 and 10 min-reaction resulted in a sufficient hydrolysis, thus, we adopted the 5 min-reaction. The resulting fatty acids were esterified for $5,10,15,20$ or $30 \mathrm{~min}$, respectively, with aqueous $\mathrm{HCl}$ in methanol solution having various $\mathrm{HCl}$ concentrations (aqueous $\mathrm{HCl} /$ methanol $=4: 1,4: 2,4: 3$ and $4: 4, \mathrm{v} / \mathrm{v})$. All operations were performed under nitrogen, and with minimum exposure to air and light.

\section{Gas-liquid chromatography}

FAMEs were analyzed on a GC-17A gaschromatograph (Shimadzu Seisaku-syo, Tokyo) equipped with a flame-ionization detector (FID) using a capillary column (SUPELCOWAX ${ }^{\mathrm{TM}} 10,60 \mathrm{~m} \times$ $0.32 \mathrm{~mm}$, i.d., $0.25 \mu \mathrm{m}$ film-thickness, SUPELCO, Inc., PA). This analysis adopted a split injection (split ratio $1: 100$ ). The $\mathrm{GC}$ analysis was temperatureprogrammed, at $195^{\circ} \mathrm{C}$ held at $8 \mathrm{~min}$, and raised from $195^{\circ} \mathrm{C}$ to $220^{\circ} \mathrm{C}$ at a rate of $2^{\circ} \mathrm{C} / \mathrm{min}$ and then held at $220^{\circ} \mathrm{C}$ for $40 \mathrm{~min}$. The injection port and detector temperatures were set at $240^{\circ} \mathrm{C}$ and $250^{\circ} \mathrm{C}$, respectively. Helium was used as the carrier gas at a rate of 2 $\mathrm{m} / / \mathrm{min}$. The peaks of the FAMEs were identified by comparing the retention times to reference standards, FAMEs standard from fish oil and CLA methyl esters standard, and the area of the c-9, $t-11$ CLA peak was calculated as $\mathrm{mg} / \mathrm{g}$ of lipid or $\mathrm{mg} / 100 \mathrm{~g}$ of sample using tricosanoic acid as an internal standard.

\section{Results and Discussion}

Figure 1 shows the respective typical capillary gasliquid chromatograms of beef lipids and CLA methyl esters standard. As shown in this figure, c-9, $t-11$ CLA isomer was separated from beef lipid, and was identified. Preliminarily, we prepared FAMEs of beef lipid by using Method I, III, IV and V (described in Materials and Methods), and compared the composition of fatty acid. Composition of $c-9, t-$ 11 CLA was $0.31 \%$ for Method I, but the other three 
TAKENOYAMA, KAWAHARA, MURATA and YAMAUCHI

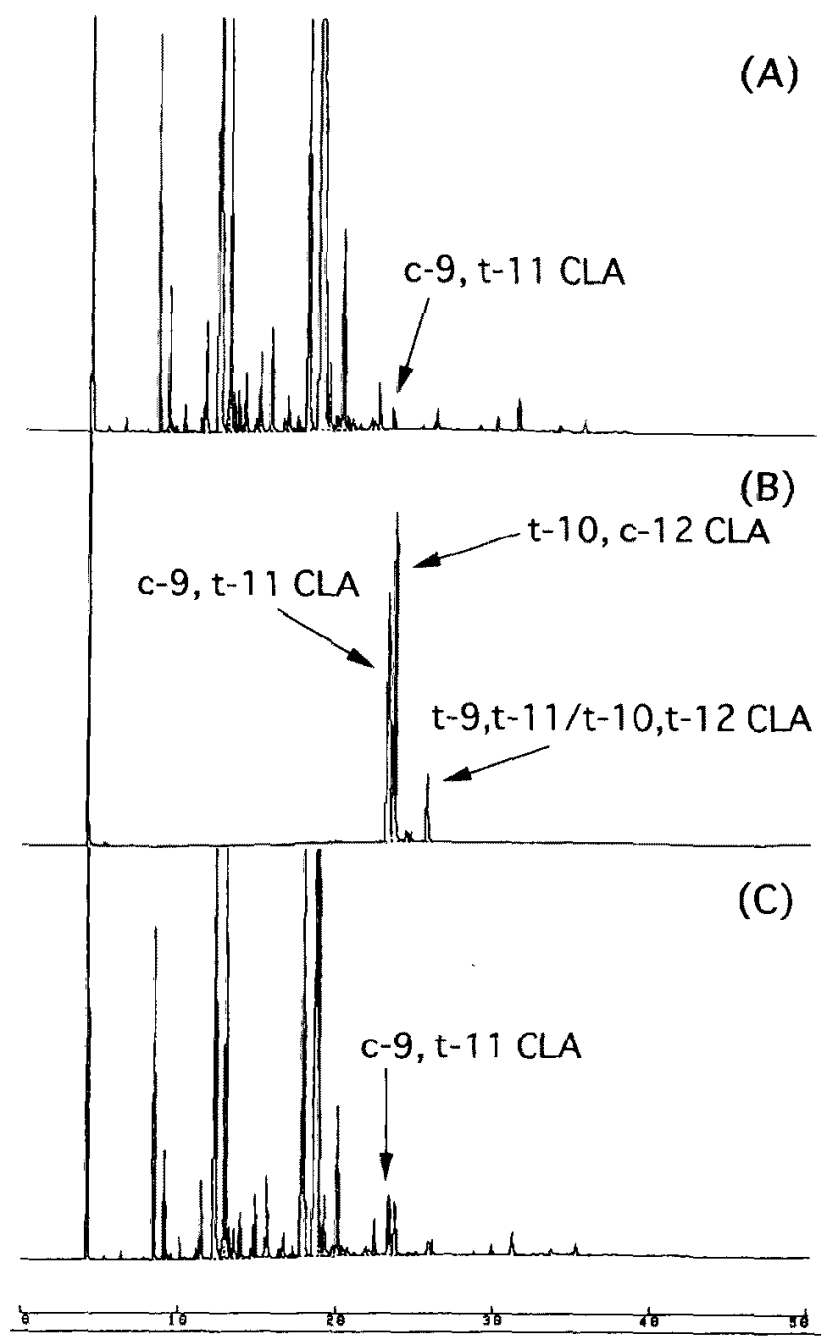

Fig. 1. Identification of conjugated linoleic acid (CLA) isomers in beef on capillary gas-liquid chromatography. Each panel shows (A) : methyl esterified beef lipid with Method I, (B) : CLA methyl esters standard, and (C): (A) + (B).

methods showed values ranging from 0.33 to $0.36 \%$. This result suggested that Method I may lead to isomerization of $\mathrm{c}-9, \mathrm{t}-11$ CLA.

In order to more precisely determine a small amount of c-9, t-11 CLA without its decomposition and isomerization, the authors continued to examine the four methods by which a higher yield of total fatty acids and a lower decomposition and isomerization of the c-9, t-11 CLA could be obtained. Methyl esterification with Methods II and $\mathrm{V}$ gave adequate yields of total fatty acids from beef lipids at 25 and 5

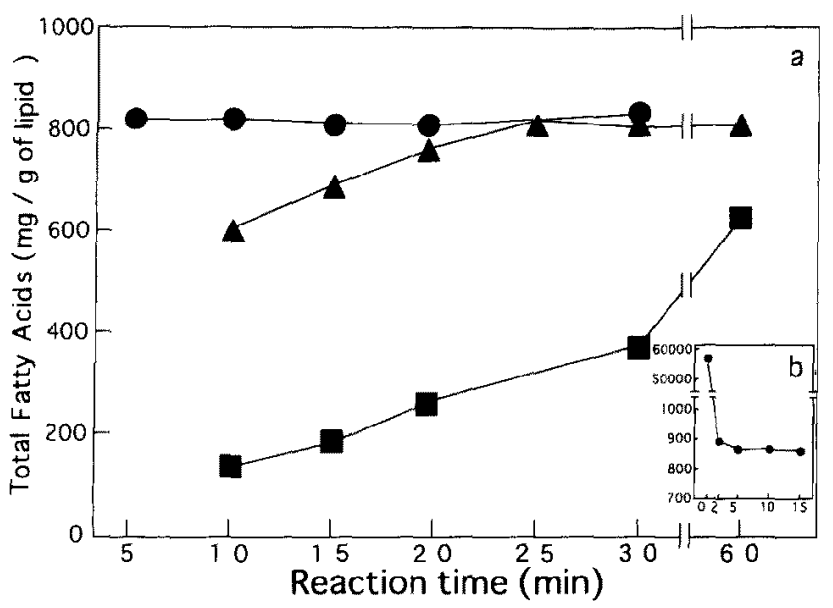

Fig. 2. Effect of esterifying time of various methods on the yield of total fatty acids from beef lipid. Each panel shows the yield of total fatty acids with a : Methods $\Pi$, III and V b : Method V.

- : Method II

- - : Method III

- : Method V

Table 1. Fatty acid content of beef lipid esterified with Methods II and V (mg/g of lipid)

\begin{tabular}{lrrrr}
\hline \hline & \multicolumn{4}{c}{ Method } \\
\cline { 2 - 5 } Fatty acids & \multicolumn{3}{c}{ II } & \multicolumn{2}{c}{$\mathrm{V}$} \\
\cline { 2 - 5 } $14: 0$ & 19.79 & $(2.46)$ & 18.27 & $(2.31)$ \\
$15: 0$ & 3.88 & $(0.48)$ & 3.65 & $(0.46)$ \\
$16: 0$ & 201.04 & $(24.94)$ & 194.44 & $(24.54)$ \\
$16: 1$ & 25.38 & $(3.15)$ & 23.90 & $(3.02)$ \\
$17: 0$ & 8.15 & $(1.01)$ & 8.03 & $(1.01)$ \\
$18: 0$ & 163.43 & $(20.28)$ & 164.07 & $(20.71)$ \\
$18: 1(\omega 9)$ & 328.41 & $(40.73)$ & 324.18 & $(40.92)$ \\
$18: 1(\omega 7)$ & 26.73 & $(3.32)$ & 26.14 & $(3.30)$ \\
$18: 2(\omega 6)$ & 13.93 & $(1.73)$ & 14.14 & $(1.78)$ \\
$18: 3(\omega 3)$ & 6.40 & $(0.79)$ & 6.51 & $(0.82)$ \\
$c-9$, t-11 CLA & 2.44 & $(0.30)$ & 2.87 & $(0.36)$ \\
$20: 1(\omega 9)$ & 1.27 & $(0.16)$ & 1.31 & $(0.17)$ \\
$20: 4(\omega 6)$ & 1.78 & $(0.22)$ & 1.59 & $(0.20)$ \\
$20: 5(\omega 3)$ & 0.86 & $(0.11)$ & 0.81 & $(0.10)$ \\
$22: 5(\omega 3)$ & 2.54 & $(0.32)$ & 2.39 & $(0.30)$ \\
\hline Total & 806.03 & $(100.00)$ & 792.30 & $(100.00)$ \\
\hline
\end{tabular}

Each value in parentheses represents composition of fatty acids. 


\section{CLA Analysis in Meat}

min, respectively, whereas the yield at $60 \mathrm{~min}$ for Method III was only about $75 \%$ as compared with the yield at $10 \mathrm{~min}$ for Method V (Fig. $2 \mathrm{a}$ ). In addition, Method IV resulted in a remarkably lower yield of total fatty acids, which corresponded to only about $10 \%$ of the yield at $10 \mathrm{~min}$ for Method V (data not shown). For Method V, there were almost no differences in the yield of total fatty acids between 5 and 10 min of esterification. On the other hand, much higher yield of total fatty acids was estimated with esterification for less than $5 \mathrm{~min}$ because of lower recovery of internal standard (Fig. 2 b). In this method, esterification for $5 \mathrm{~min}$ was performed since a longer reaction time in transmethyl esterification could cause an isomerization of CLA isomers. The results obtained in this study showed that Methods II and $\mathrm{V}$ were superior to both Methods III and V in terms of the yield of total fatty acids.

There were no significant differences in the composition of fatty acids of beef lipid between Methods II and V, and the yield of total fatty acid for Method V was approximately 98\% that for Method II (Table

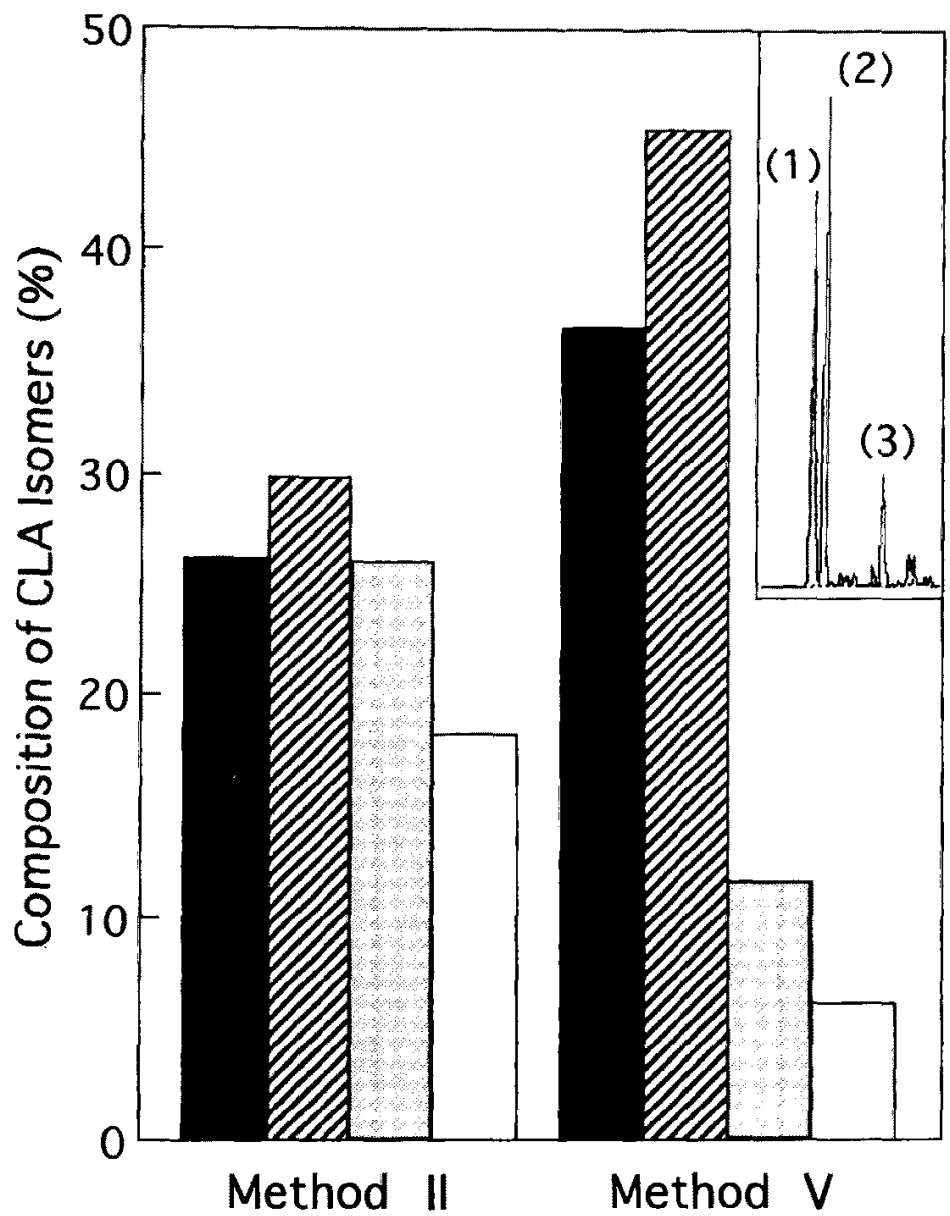

Fig. 3. Effect of esterifying procedures on the composition of CLA isomers. "others" represent total CLA peaks except $\mathrm{c}-9, \mathrm{t}-11 ; \mathrm{t}-10, \mathrm{c}-$ $12 ; \mathrm{t}-9, \mathrm{t}-11$ and $\mathrm{t}-10, \mathrm{t}-12$ CLA isomers.

: c-9, t-11 CLA isomer (1)

$\square: \mathrm{t}-10, \mathrm{c}-12$ CLA isomer (2)

$\square: t-9, t-11$ and $t-10, t-12$ CLA isomers (3)

$\square$ : others 


\section{TAKENOYAMA, KAWAHARA, MURATA and YAMAUCHI}

1). However, when we used Methods II and V for methyl esterification of free CLAs standard, Method II resulted in a lower composition of $\mathrm{c}-9, \mathrm{t}-11$ CLA than that of Method V (Fig. 3). In this figure, "others" represented a sum of other CLA isomers except $\mathrm{c}-9, \mathrm{t}-11 ; \mathrm{t}-10, \mathrm{c}-12 ; \mathrm{t}-9, \mathrm{t}-11$ and $\mathrm{t}-10, \mathrm{t}-12$ CLA isomers, therefore, c-9, t-11 and t-10, c-12 CLA isomers were possibly isomerized to the other CLA isomers. This result suggested that the presence of $\mathrm{BF}_{3}$ in reaction systems may easily induce the decomposition and isomerization of c-9, t-11 CLA isomer.

The effects of varying concentrations of $\mathrm{HCl}$ in the methyl esterification reagent on composition of CLA isomers were examined. Decomposition and isomerization of $\mathrm{c}-9, \mathrm{t}-11$ and $\mathrm{t}-10, \mathrm{c}-12$ CLA isomers by using aqueous $\mathrm{HCl} /$ methanol solution $(4: 4, \mathrm{v} / \mathrm{v}$ ) were lower than those by other higher $\mathrm{HCl}$ conditions (Fig. 4). These results indicated that decomposition and isomerization of $\mathrm{c}-9, \mathrm{t}-11$ CLA isomer were affected by aqueous $\mathrm{HCl}$ concentration in methanol solution, i.e., more acidic condition would accelerate the

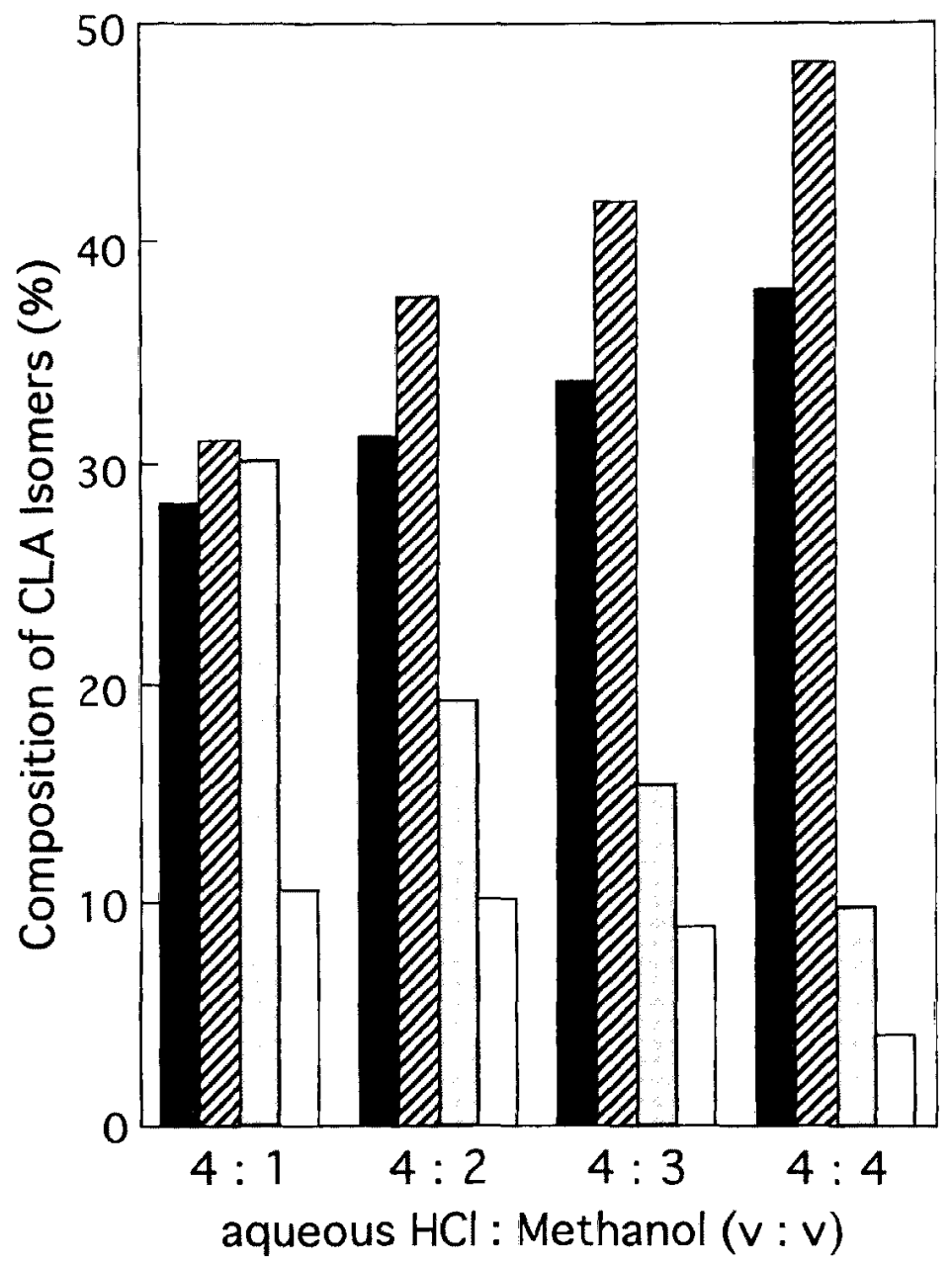

Fig. 4. Effect of $\mathrm{HCl}$ concentrations of aqueous $\mathrm{HCl} /$ methanol as esterifying reagent on the composition of CLA isomers.
a: c-9, t-11 CLA isomer
Q: $\mathrm{t}-10, \mathrm{c}-12$ CLA isomer
$\square: t-9, t-11$ and $t-10, t-12$ CLA isomers
$\square$ : others 


\section{CLA Analysis in Meat}

Table 2. Comparison between the composition of CLA methyl esters standard and that prepared from free CLAs standard with Method V

\begin{tabular}{ccccc}
\hline Isomers & $c-9, \mathrm{t}-11$ & $\mathrm{t}-10, \mathrm{t}-12$ & $\begin{array}{c}\mathrm{t}-9, \mathrm{t}-11 \text { and } \\
\mathrm{t}-10, \mathrm{t}-12\end{array}$ & Others \\
\hline \multirow{2}{*}{ A } & 39.06 & 46.15 & 9.50 & 5.29 \\
& $(0.26)$ & $(0.27)$ & $(0.05)$ & $(0.48)$ \\
\multirow{2}{*}{ B } & 36.80 & 46.18 & 10.83 & 6.21 \\
& $(0.47)$ & $(0.16)$ & $(2.00)$ & $(0.67)$
\end{tabular}

A : CLA methyl esters standard,

B : CLA methyl esters derived from free CLAs standard with Method V.

Each value in parentheses represents standard deviation $(n=4)$.

Table 3. c-9, $\mathrm{t}-11$ CLA content of various meats

\begin{tabular}{lc}
\hline Meat & $\mathrm{c}-9, \mathrm{t}-11$ CLA \\
\hline & $(\mathrm{mg} / \mathrm{g}$ of lipid $)$ \\
\hline Beef & 3.21 \\
Mutton & 2.28 \\
Goat meat & 6.35 \\
Pork & 0.63 \\
Chicken & 0.56 \\
\hline
\end{tabular}

decomposition and isomerization of $\mathrm{c}-9, \mathrm{t}-11$ and $\mathrm{t}-10$, c-12 CLA. The composition of c-9, $t-11$ CLA isomer prepared from free CLA standard by Method $V$ using aqueous $\mathrm{HCl} /$ methanol solution $(4: 4, \mathrm{v} / \mathrm{v})$, however, decreased by $5.8 \%$ compared with that of CLA methyl esters standard (Table 2).

As a result of the investigation of some preparation procedures of fatty acid methyl esters, we could develop a modified method for determining c-9, t-11 CLA content in meat by dividing the value estimated using tricosanoic acid as an internal standard by 0.9261 , which was a correction factor determined on the basis of the yield of total fatty acids and the decomposition ratio of $c-9, t-11$ CLA. In addition, this method can be used not only for determination of c-9, t-11 CLA but also for a routine analysis of fatty acids because it is easy to use and is less time consuming.

Table 3 shows the c-9, t-11 CLA content of some meat samples determined by the proposed method.
Chin et al. ${ }^{2)}$ found that CLA content of ruminant animal products was especially high in total CLAs and in c-9, $t-11$ CLA ratio of total CLAs. The c-9, $t-11$ CLA contents in their study were very similar to our values determined. Besides, in this study, meat from goats fed with roughage contained the highest amount of c-9, t-11 CLA. Stanton et al. ${ }^{16)}$ reported that some milk from low grass allowance $(16 \mathrm{~kg} /$ cow $\times$ day $)$ have lower CLA values than high grass allowance (20 and $24 \mathrm{~kg} / \mathrm{cow} \times$ day) after 19 week treatment. These results indicate that excessive feeding of roughage to ruminant animals and feeding system may lead to changes in the microflora of their rumen, which may alter the content of c-9, t-11 CLA in meat and milk products.

\section{Acknowledgements}

This study was supported in part by a Grant-in-Aid for Scientific Research from the Ministry of Education, Science and Culture of Japan and by a grant from the Ito Memorial Foundation, Tokyo.

\section{References}

1) American Oil Chemists' Society. Officialmethods. In : AOCS. Ce2-66. Champaign. 1973.

2) Chin SF, Liu W, Storkson JM, Ha YL, Pariza MW Dietary sources of conjugated dienoic isomers of linoleic acid, a newly recognized class of anticarcinogens. Journal of Food Composition and Analysis, $5:$ 185-197. 1992.

3) Folch J, Lees M, Sloane Stanley GH. A simple method for the isolation and purification of total lipides from animal tissues. Journal of Biological Chemistry, $226: 497-509.1957$.

4) Ha YL, Storkson JM, Scimeca JA, Pariza MW. Inhibition of benza(a)pyrene-induced mouse fore stomach neoplasia by conjugated dienoic derivatives of linoleic acid. Cancer Research, 50 : 1097-1101. 1991.

5) Ha YL, Grimn NK, Pariza MW. Anticarcinogens from fried ground beef : heat-altered derivatives of linoleic acid. Carcinogenesis, 8: 1881-1887. 1987.

6) Ha YL, Grimn NK, Pariza MW. Newly recognized anticarcinogenic fatty acids : Identification and quantification in natural and processed cheeses. Journal of Agricultural Food Chemistry, 37 : 75-81. 1989.

7) Hughes PE, Hunter WJ, Tove SB. Biohydrogenation 


\section{TAKENOYAMA, KAWAHARA, MURAT $\Lambda$ and YAMAUCHI}

of unsaturated fatty acids: Purification and properties of cis-9, trans-11-octadecadienate reductase. Journal of Biological Chemistry, 257:3643-3649. 1982.

8) Ip C, Chin SF, Scimeca JA, Pariza MW. Mammary cancer prevention by conjugated dienoic derivative of linoleic acid. Cancer Research, $51: 6118-6124$. 1991.

9) Jham GN, Teles FFF, Campos LG. Use of aqueous $\mathrm{HCl} /$ methanol as esterification reagent for analysis of fatty acids derived from soybean lipids. Journal of American Oil Chemists' Society, 59 : 132 133. 1982.

10) Lee L, Krichevsky D, Pariza MW. Conjugated linoleic acid and atherosclerosis in rabbit. Atherosclerosis, $108: 19-25.1994$.

11) Morrison WR, Smith LM. Preparation of fatty acid methyl esters and dimethylacetals from lipids with boron fluoride-methanol. Journal of Lipid Research, 5: 600-608. 1964.

12) Nicilosi RJ, Courtemanche KV, Laitinen L, Scimeca JA, Huth PJ. Effect of feeding diets enriched in conjugated linoleic acid on lipoproteins and aortic atherogenesis in hamsters. Circulation, 88 (Supplement 1) : 2458.1993.

13) Pariza MW, Ashoor SH, Chu FS, Lund DB. Effects of temperature and time on mutagen formation in pan-fried hamburger. Cancer Letter, 7 : 63-69. 1979.

14) Shantha CN, Decker EA, Hennig B. Comparison of methylation methods for the quantitation of conjugated linoleic acid isomers. Journal of $A O A C$. International, $76: 644-649.1993$.

15) Shuchardt U, Lopes OC. Tetramethylguanidine catalyzed transestcrification of fats and oils : A new method for rapid determination of their composition. Journal of American Oil Chemists' Society, $65: 1940$ $-1941.1988$.

16) Stanton C, Lawless F, kjellmer G, Harrington D, Devery $\mathbf{R}$, Connolly JF, Murphy $\mathbf{J}$. Dietary influences on bovine milk cis-9, trans-11 conjugated linoleic acid content. Journal of Food Science, 62 : 1083-1086. 1997 